\title{
ASSESSMENT OF THE TOTAL SOLIDS AND FAT CONTENTS IN WHOLE LIQUID EGG PRODUCTS BY ELECTRICAL AND THERMAL CONDUCTIVITY MEASUREMENTS
}

\author{
Annachiara Berardinelli, Luigi Ragni, Chiara Cevoli, Adriano Guarnieri
}

\section{Introduction}

According to Italian industry demands and food formulation, whole liquid egg products used as ingredients are characterized by a total solids (TS) content ranging between $20 \%$ and $26 \%$. The whole liquid egg products are generally obtained from the breakage and the subsequent homogenization of the egg constituents. As the content of solids in whole egg is affected by the yolk to white ratio and by the yolk and white chemical compositions [Washburn 1979], the homogenized product should be corrected in order to produce ingredients characterized by a certain total solids content value. The yolk to white ratio is in turn related to the egg size that increases with the age of the hen [Fletcher 1983] and both the yolk and white total solids content can be influenced by the hen's strain [Ahn 1997].

Since the albumen and yolk are composed of really different percentages of water and chemical components [Stadelman 1995], electrical [Żywica 2005] and thermal [Ahmed 2008] conductivity measurements could be used to assess, rapidly and economically, the quality of whole liquid egg products in terms of total solids and fat contents.

Electrical conductivity is a measure of the transmission of an electric current through a material; foods containing charged electrolytes are able to transmit an electric current in relation to their electrical resistance $\mathrm{R}$ value [Figura 2007]. In addition to the concentration and type of the ions, electrical conductivity is strongly dependent on temperature; conductivity readings often refer to a specific temperature, typically $20^{\circ} \mathrm{C}$ or $25^{\circ} \mathrm{C}$, obtained by calculating a temperature coefficient $(\theta)$ expressed as a conductivity variation in $\% /{ }^{\circ} \mathrm{C}$ [Barron 2007]. Furthermore,

Paper received 03.06.2010; accepted 20.10.2010

ANNACHIARA BERARdinelli PhD; LUIGI Ragni, researcher; ChIARA Cevoli, PhD; Adriano Guarnieri, full professor - Department of Agricultural Economics and Engineering DEIAgra, University of Bologna, P.zza Goidanich, 60, Cesena FC. e-mail: annachi.berardinelli@unibo.it Tel. 0039.0547636 the cell characteristics and the applied current affect the polarization at the electrodes, an accumulation of ionic species near the electrode surfaces, which may lead to erroneous readings [Radiometer Analytical SAS, 2004].

To date, electrical conductivity is widely used for water control [ISO 7888:1985] and in the dairy industry for quality analyses of milk [Henningsson 2005] and cheese fermentation processes [Paquet 2000]; electrical property measurements are also important during food processes which are based on Ohmic heating [Fryer 1993] and pulsed electric field treatments used for microbial inactivation of liquids such as juice-milk based beverages [Sampedro 2007] and liquid egg products [Amiali 2006]. In particular, Amiali 2006, showed a positive linear correlation between electrical conductivity and temperature for different liquid egg products and for albumen and yolk.

Similarly, thermal conductivity is a food property necessary for the setting-up of thermal treatment such as refrigeration, freezing, pasteurization and heating processes in order to avoid possible product damage [Ahmed 2008]. As regards the influence of temperature, discordant data have been reported in the literature: with the increase of the temperature, slight decreases [Gut 2005; Coimbra 2006] and increases [Fontana 1999] of thermal conductivity were observed.

Based on electrical and thermal conductivity measurements, the present research intends to assess the total solids and fat contents of whole liquid egg products characterized by different percentages of albumen and yolk. The effect of the solution temperature on the electrical and thermal properties was also studied.

\section{Materials and methods}

A total of 60 brown eggs were collected from a local poultry farm one day after laying and the main quality indices were assessed: mass (g), diameter $(\mathrm{mm})$, height $(\mathrm{mm})$, air cell height $(\mathrm{mm})$, thick albumen height $(\mathrm{mm})$ and yolk index. The air cell height was obtained by averaging four measurements carried 
out from the base of the shell to three equidistant points on the circumference described by the contact line of the membrane to the shell and in the middle point of the same membrane. The thick albumen was calculated by averaging three measurements taken at different points of the thick albumen at a distance of $10 \mathrm{~mm}$ from the yolk. The yolk index was obtained by dividing the height by the diameter of the yolk [Funk 1948].

The albumen and yolk content coming from each egg were respectively divided in two batches; each batch was then manually mixed very slowly and 9 whole egg liquid products $(300 \mathrm{ml}$ each $)$, characterized by different percentages (in mass) of the two components (Tab.1), were prepared using an analytical balance (Sartorius, BL 120 S, Sartorius mechatronics, Italy) and homogenised (Ultra-Turrax, IKA, Germany). The percentages of white and yolk in the mixtures were selected in order to cover, as much as possible, the range of the total solids (TS) content characterizing the commercial whole liquid egg products prepared for the Italian food industry. Measurements were carried out both on the whole liquid egg products and the albumen and yolk samples.

Electrical conductivity $(\mathrm{mS} / \mathrm{cm})$ was measured as an average of three replicates by means of a 4-pole platinum cell (SPT06, DeltaOHM, Italy) containing a temperature sensor (Pt100), connected to a portable conductivity meter (HD2306.0, DeltaOHM, Italy). Before measurements, the device was calibrated by means of both standard solutions of $0.01 \mathrm{~mol} / \mathrm{l}$ and $0.1 \mathrm{~mol} / \mathrm{l}$ of $\mathrm{KCL}$, characterized, at $25^{\circ} \mathrm{C}$, by electrical conductivity values of $1.413 \mathrm{mS} / \mathrm{cm}$ and 12.88 $\mathrm{mS} / \mathrm{cm}$.

Since the conductivity of egg solutions of electrolytes increases as the temperature increases, the conductivity values were obtained from 2 to $28^{\circ} \mathrm{C}$ (with steps of about $4^{\circ} \mathrm{C}$ ) in order to assess the temperature coefficient $(\theta)$ usually expressed as a conductivity variation in $\% /{ }^{\circ} \mathrm{C}$. This coefficient was calculated at the reference temperature of $20^{\circ} \mathrm{C}$.

Thermal conductivity $(\mathrm{W} / \mathrm{mK})$ was determined as a mean of three replicates using a specific needle probe named KD2 (Decagon Devices, Inc., Pullman, WA,
USA). This consists of a hand-held reader and a single-needle sensor that can be inserted into the medium under test; a short duration thermal pulse is applied to the heater and the temperature of the thermocouple response is used to simultaneously determine the thermal conductivity and thermal diffusivity. The whole liquid egg products and the albumen and the yolk samples were put into 11 graduated cylinders $(50 \mathrm{ml})$ and the thermal conductivity was directly measured by the probe at two temperatures, 0 and $20^{\circ} \mathrm{C}$ respectively. It was important to wait for about 5 minutes between successive readings, to allow thermal equilibrium.

The total solids (TS) and the fat contents of the liquid egg products were assessed in triplicates according to the AOAC Official Method No. 925.30 [1990] and Folch [1957], respectively.

Regression models for the prediction of the total solids (TS) and the fat contents were obtained from both electrical and thermal conductivity measurements conducted for the whole egg liquid products at the reference temperature of $20^{\circ} \mathrm{C}$ (SPSS, version 15 , USA).

\section{Results and discussion}

Averaged values of the analysed quality indices mass $(\mathrm{g})$, diameter $(\mathrm{mm})$, height $(\mathrm{mm})$, air cell height $(\mathrm{mm})$, thick albumen height $(\mathrm{mm})$ and yolk index are shown in Table 2 .

The analysed samples were characterized by mean values of the total solids (TS) content of $11.9 \%$ and $50.3 \%$ respectively for $100 \%$ of albumen and $100 \%$ of yolk (Tab. 3); the TS values for the mixtures ranged between $21.3 \%$ and $31.3 \%$ (mean step of $1.3 \%$ ). The fat content of the mixtures ranged between $8.4 \%$ and $15.4 \%$ (mean step of $0.9 \%$ ) and, it was $0.03 \%$ and $30.4 \%$ for the albumen and yolk samples, respectively.

Figure 1 shows the mean values of the electrical conductivity $(\mathrm{mS} / \mathrm{cm})$ of the whole liquid egg products in the temperature range of $2^{\circ} \mathrm{C}-28^{\circ} \mathrm{C}$. As expected, the highest electrical conductivity was measured for the albumen $\left(8.1 \mathrm{mS} / \mathrm{cm}\right.$ at $\left.20^{\circ} \mathrm{C}\right)$ and the

\begin{tabular}{|c|c|c|c|c|c|c|c|c|c|}
\hline \multirow{2}{*}{$\begin{array}{c}\text { Egg } \\
\text { component }\end{array}$} & \multicolumn{9}{|c|}{ Whole liquid egg products } \\
\hline & 1 & 2 & 3 & 4 & 5 & 6 & 7 & 8 & 9 \\
\hline Albumen (\%) & 75 & 72 & 69 & 66 & 62 & 59 & 56 & 53 & 50 \\
\hline Yolk (\%) & 25 & 28 & 31 & 34 & 38 & 41 & 44 & 47 & 50 \\
\hline
\end{tabular}

TABLE 1 - Percentage of egg white and yolk in the 9 analysed whole egg liquid products. 


\begin{tabular}{|l|c|c|}
\hline \multicolumn{1}{|c|}{ Quality index } & Average & SD \\
\hline Mass (g) & 67 & 7 \\
Diameter (mm) & 45 & 2 \\
Height (mm) & 60 & 3 \\
Thick albumen height (mm) & 4.9 & 1.3 \\
Air cell height (mm) & 4.4 & 0.5 \\
yolk index & 0.45 & 0.11 \\
\hline
\end{tabular}

TABLE 2 - Main quality parameters of the eggs used to prepare the whole liquid egg products.

\begin{tabular}{|c|c|c|c|c|c|}
\hline \multirow{2}{*}{\multicolumn{2}{|c|}{ Analysed samples }} & \multicolumn{2}{|c|}{$\begin{array}{l}\text { Total solids content } \\
\qquad(\%)\end{array}$} & \multicolumn{2}{|c|}{$\begin{array}{l}\text { Fat content } \\
\qquad(\%)\end{array}$} \\
\hline & & Average & SD & Average & $\mathrm{SD}$ \\
\hline \multicolumn{2}{|l|}{ Albumen } & 11.9 & 0.40 & 0.03 & 0.005 \\
\hline \multirow{9}{*}{$\begin{array}{l}\text { Whole liquid } \\
\text { egg products* }\end{array}$} & 1 & 21.3 & 0.02 & 8.4 & 0.03 \\
\hline & 2 & 22.6 & 0.03 & 8.5 & 0.04 \\
\hline & 3 & 23.9 & 0.09 & 9.8 & 0.20 \\
\hline & 4 & 25.2 & 0.02 & 10.9 & 0.02 \\
\hline & 5 & 26.5 & 0.09 & 11.7 & 0.05 \\
\hline & 6 & 27.6 & 0.23 & 12.6 & 0.01 \\
\hline & 7 & 29.1 & 0.06 & 13.5 & 0.08 \\
\hline & 8 & 30.1 & 0.12 & 14.6 & 0.13 \\
\hline & 9 & 31.3 & 0.06 & 15.4 & 0.09 \\
\hline \multicolumn{2}{|l|}{ Yolk } & 50.3 & 0.06 & 30.4 & 0.11 \\
\hline
\end{tabular}

TABLE 3 - Total solids (TS) and fat contents (\%) of the analysed whole liquid egg products. *see table 1 .

lowest for the yolk $\left(2.6 \mathrm{mS} / \mathrm{cm}\right.$ at $\left.20^{\circ} \mathrm{C}\right)$. This behaviour is mainly due to high levels of moisture content and mineral concentration characterizing the egg white and to the yolk fat content that acts as an insulator [Amiali 2006]. The electrical conductivity of the analysed whole liquid egg products (from $75 \%$ to $50 \%$ of albumen) ranged, at $20^{\circ} \mathrm{C}$, from $5 \mathrm{mS} / \mathrm{cm}$ to $6.5 \mathrm{mS} / \mathrm{cm}$. Differences between the electrical conductivity values of the egg mixtures increased with the temperature; at $20^{\circ} \mathrm{C}$ a mean conductivity difference of $0.18 \mathrm{mS} / \mathrm{cm}$ was observed between the nine whole liquid egg products.

The relationship between electrical conductivity and temperature follows a linear trend. The model regressions, the coefficient of determination $\mathrm{R}^{2}$ (up to $0.9999)$ and the temperature coefficient $\theta_{20^{\circ} \mathrm{C}}\left(\% /{ }^{\circ} \mathrm{C}\right)$ are shown in Table 4. According to the linear depend- ence, the temperature coefficient $(\theta)$ was calculated by using the linear correction:

$$
\theta_{20^{\circ} \mathrm{C}}=\frac{\left(E c_{T}-E c_{20^{\circ} \mathrm{C}}\right) \times 100}{E c_{20^{\circ} \mathrm{C}}\left(T-20^{\circ} \mathrm{C}\right)}
$$

where $\mathrm{T}$ and $20^{\circ} \mathrm{C}$ are the temperatures at which electrical conductivities $\mathrm{Ec}_{\mathrm{T}}$ and $\mathrm{Ec}_{20^{\circ} \mathrm{C}}$ were respectively measured. The $\theta_{20^{\circ} \mathrm{C}}$ values reported reflect the basic behaviour of the albumen, yolk and whole liquid egg products [Barron 2007].

The results of the thermal conductivity measurements conducted at $0^{\circ} \mathrm{C}$ and $20^{\circ} \mathrm{C}$ are reported in Table 5. Also for this parameter, the moisture content justifies the higher values observed for the albumen [Ahmed 2008]. As reported in the literature [Gut 


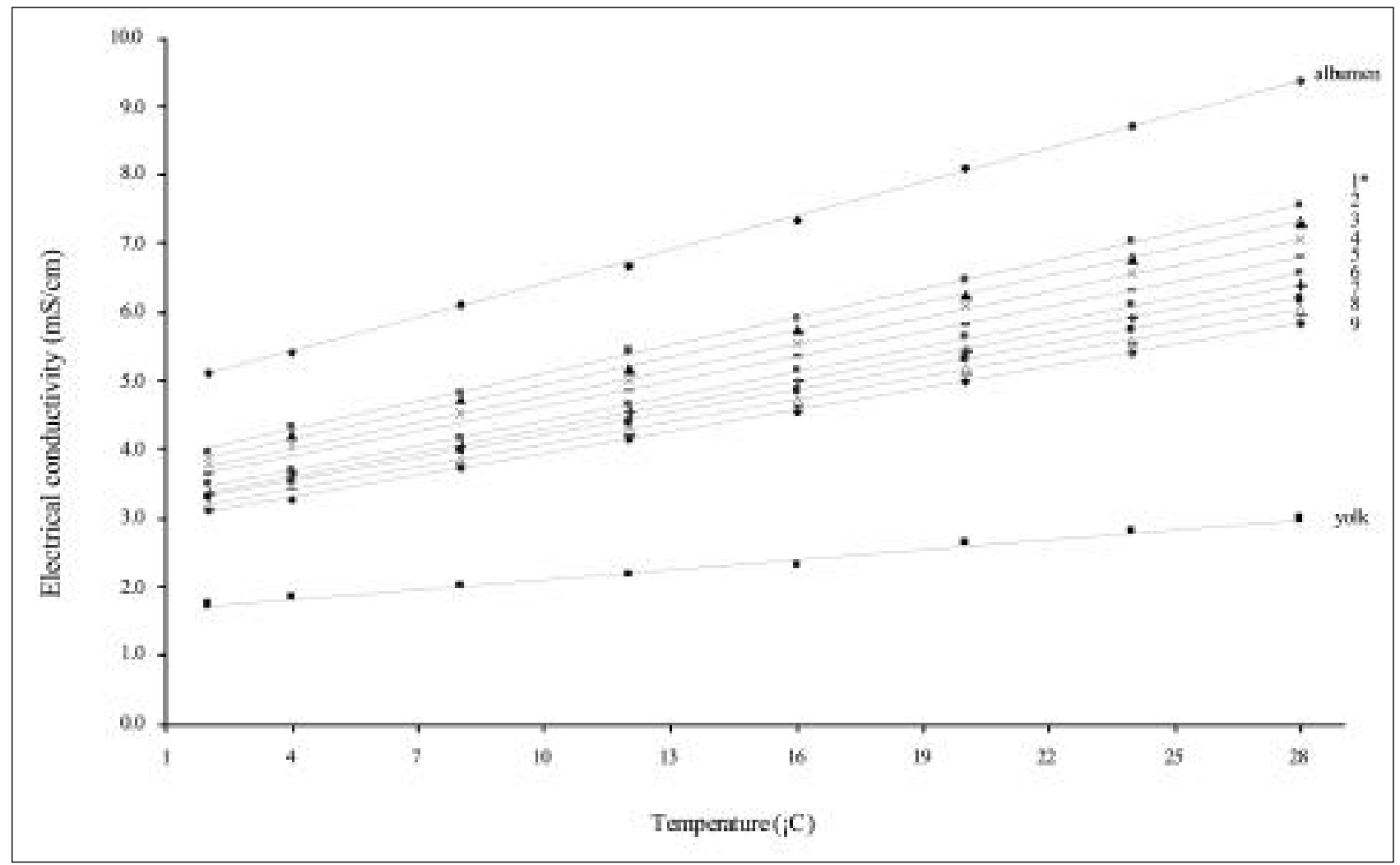

Fig. 1 - Electrical conductivity $(\mathrm{mS} / \mathrm{cm})$ of albumen, yolk and whole liquid egg products $(*$, see table 1$)$ versus temperature $\left({ }^{\circ} \mathrm{C}\right)$.

2004; Coimbra 2006], the thermal conductivity values of the analysed samples were not greatly influenced by the temperature: a mean decrement of about $1 \%$ was measured passing from $0^{\circ} \mathrm{C}$ to $20^{\circ} \mathrm{C}$. At $20^{\circ} \mathrm{C}$, a mean conductivity difference of $0.007 \mathrm{~W} / \mathrm{mK}$ was ob- served between the nine whole liquid egg products, characterized by a range of $0.510-0.455 \mathrm{~W} / \mathrm{mK}$.

The correlations of the total solids and fat contents with the electrical and thermal conductivity values obtained at $20^{\circ} \mathrm{C}$ for the whole liquid egg products are

\begin{tabular}{|c|c|c|c|c|}
\hline \multicolumn{2}{|c|}{ Analysed samples } & Regression equation & $\mathrm{R}^{2}$ & $\begin{array}{l}\theta_{20^{\circ} \mathrm{C}} \\
\left(\% /{ }^{\circ} \mathrm{C}\right)\end{array}$ \\
\hline \multicolumn{2}{|c|}{ Albumen } & $\mathrm{Ec}=0.1644 \mathrm{~T}+4.7561$ & 0.9994 & 2.1 \\
\hline \multirow{9}{*}{$\begin{array}{l}\text { Whole } \\
\text { liquid egg } \\
\text { products* }\end{array}$} & 1 & $\mathrm{Ec}=0.137 \mathrm{~T}+3.7277$ & 0.9994 & 2.1 \\
\hline & 2 & $\mathrm{Ec}=0.1319 \mathrm{~T}+3.6221$ & 0.9990 & 2.1 \\
\hline & 3 & $\mathrm{Ec}=0.1263 \mathrm{~T}+3.5116$ & 0.9995 & 2.1 \\
\hline & 4 & $\mathrm{Ec}=0.1215 \mathrm{~T}+3.3846$ & 0.9998 & 2.1 \\
\hline & 5 & $\mathrm{Ec}=0.1201 \mathrm{~T}+3.2139$ & 0.9995 & 2.1 \\
\hline & 6 & $\mathrm{Ec}=0.1157 \mathrm{~T}+3.1414$ & 0.9997 & 2.1 \\
\hline & 7 & $\mathrm{Ec}=0.1102 \mathrm{~T}+3.0912$ & 0.9999 & 2.1 \\
\hline & 8 & $\mathrm{Ec}=0.1081 \mathrm{~T}+2.993$ & 0.9994 & 2.1 \\
\hline & 9 & $\mathrm{Ec}=0.1058 \mathrm{~T}+2.8685$ & 0.9998 & 2.1 \\
\hline \multicolumn{2}{|c|}{ Yolk } & $\mathrm{Ec}=0.0483 \mathrm{~T}+1.6139$ & 0.9923 & 1.9 \\
\hline
\end{tabular}

TABLE 4 - Linear regression models and temperature coefficients for albumen, yolk and whole liquid egg products. ${ }^{*}$ See table 1 ; Ec: electrical conductivity $(\mathrm{mS} / \mathrm{cm})$; T: temperature $\left({ }^{\circ} \mathrm{C}\right) ; \theta_{20}{ }^{\circ} \mathrm{C}$ t temperature coefficient $\left(\% /{ }^{\circ} \mathrm{C}\right)$. 


\begin{tabular}{|cc|c|c|}
\hline \multirow{2}{*}{ Analysed samples } & \multicolumn{2}{|c|}{$\begin{array}{c}\text { Thermal conductivity } \\
\text { (W/mK) }\end{array}$} \\
\cline { 3 - 4 } & & $0^{\circ} \mathrm{C}$ & $20^{\circ} \mathrm{C}$ \\
\hline \multicolumn{2}{|c|}{ Albumen } & 0.556 & 0.549 \\
\hline & 1 & 0.518 & 0.510 \\
& 2 & 0.510 & 0.505 \\
& 3 & 0.505 & 0.495 \\
Whole liquid & 4 & 0.495 & 0.488 \\
egg products* & 5 & 0.485 & 0.478 \\
& 6 & 0.478 & 0.472 \\
& 7 & 0.472 & 0.467 \\
& 8 & 0.461 & 0.459 \\
& 9 & 0.457 & 0.455 \\
\hline Yolk & & 0.370 & 0.369 \\
\hline
\end{tabular}

TABLE 5 - Thermal conductivity (W/mK) of albumen, yolk and whole liquid egg products (*, see table 1 ) at $0^{\circ} \mathrm{C}$ and $20^{\circ} \mathrm{C}$.
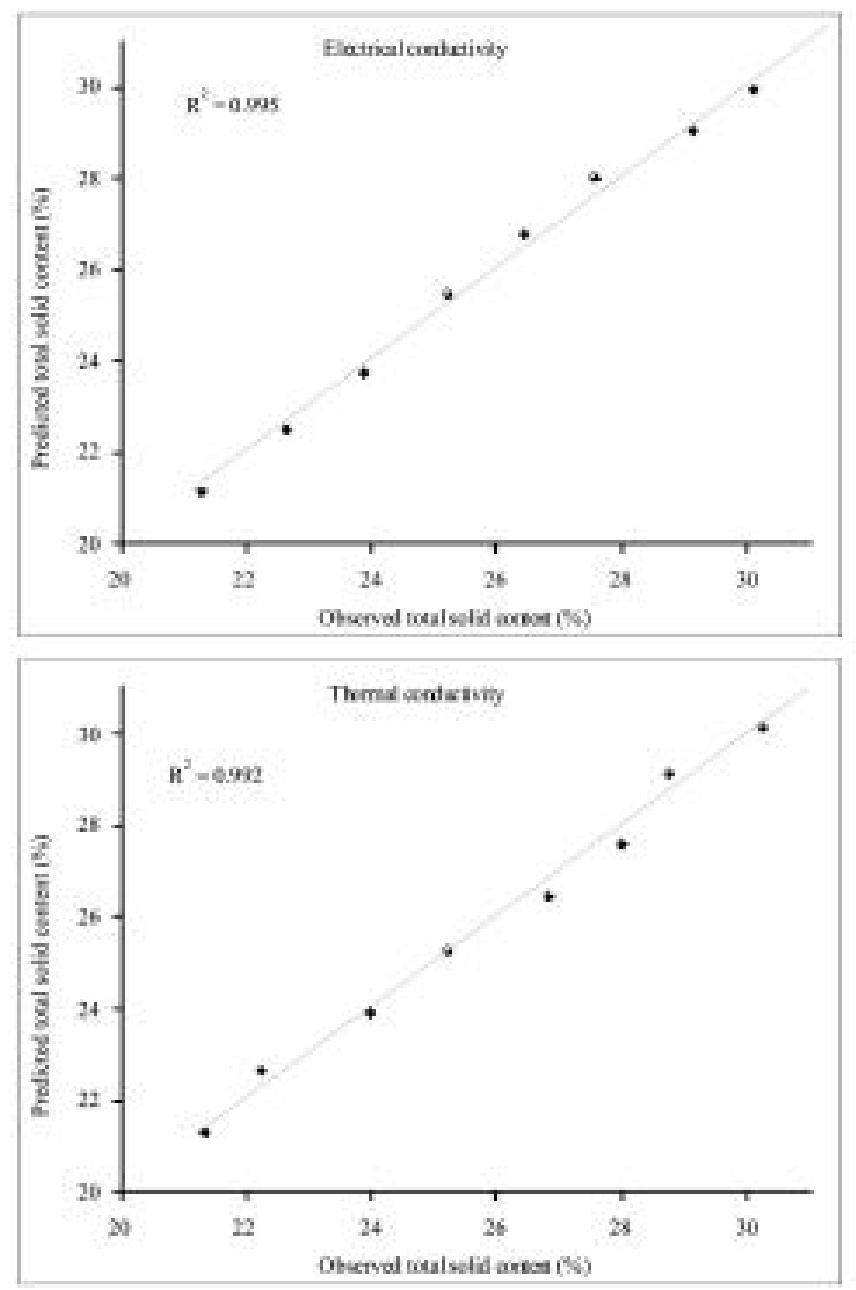

indicated in Table 6. This dependence was linear for both dependent variables and conductivity measurements. For both electrical and thermal conductivities, the best models were linear with $\mathrm{R}^{2}$ values of 0.995 and 0.992 for the total solids content, respectively; the $\mathrm{R}^{2}$ values of 0.985 and 0.990 for the prediction of the fat content, respectively, were slightly lower. The values predicted by the models versus the observed values of the two parameters for electrical and thermal conductivity are reported in Figure 2.

According to the results in Table 6 and in Figure 2, the total solids content can be predicted with a maximum error of $0.41 \%$ and $0.43 \%$ for electrical and thermal conductivity values, respectively; for the fat content, the maximum errors were $0.56 \%$ and $0.42 \%$, respectively.

\section{Conclusions}

The results of the present research showed that the conductivity measurements carried out on the whole liquid egg products are able to predict the total solids and the fat contents with an acceptable error. Both quality parameters can be estimated with linear mod-
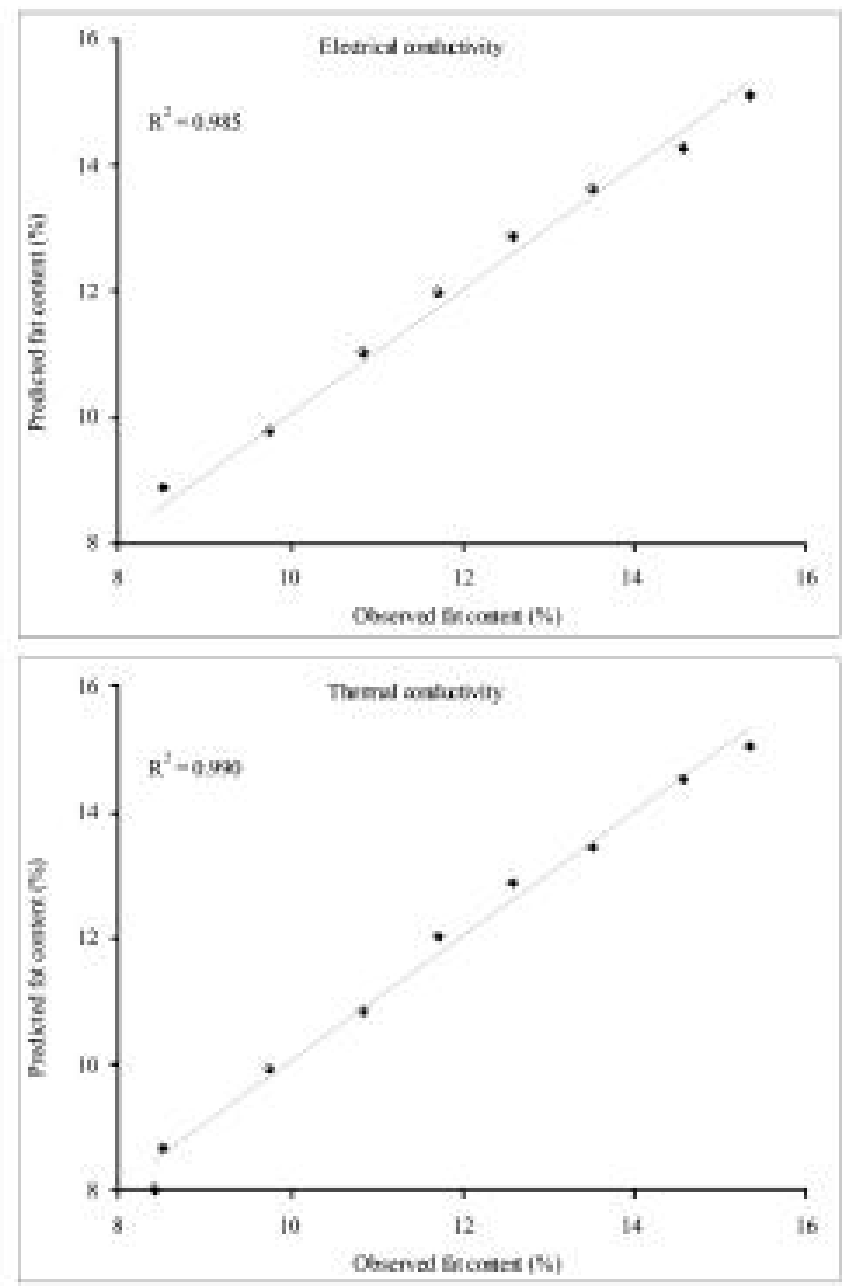

Fig. 2 - The values predicted by the models versus the observed values of the total solids and fat contents (\%) from electrical and thermal conductivity measurements. 


\begin{tabular}{|c|c|c|c|}
\hline Linear regression equation & $\mathrm{R}^{2}$ & p-level & $\mathrm{SE}(\%)$ \\
\hline $\mathrm{TS}=-6.857 * \mathrm{Ec}+65.373$ & 0.995 & 0.000 & 0.27 \\
$\mathrm{FC}=-4.993 * \mathrm{Ec}+40.070$ & 0.985 & 0.000 & 0.33 \\
$\mathrm{TS}=-172.967 * \mathrm{Tc}+109.605$ & 0.992 & 0.000 & 0.33 \\
$\mathrm{FC}=-126.449 * \mathrm{Tc}+72.521$ & 0.990 & 0.000 & 0.27 \\
\hline
\end{tabular}

TABLE 6 - Linear regression models for the total solids (TS, \%) and fat (FC, \%) contents estimation from electrical $(\mathrm{Ec}, \mathrm{mS} / \mathrm{cm})$ and thermal $(\mathrm{Tc}, \mathrm{W} / \mathrm{mK})$ conductivity measurements. SE: Standard Error.

els characterized by $\mathrm{R}^{2}$ values ranging from 0.985 to 0.995; the best model was obtained for the assessment of the total solids content from the electrical conductivity. A simple device based on these properties could represent a useful and economic tool for the rapid quality evaluation of whole liquid egg products during their preparation and subsequent use by the food industry.

As reported in the literature, the electrical conductivity was greatly influenced by the temperature of the product, with a mean percentage increase in conductivity of $2.1(\%)$ for a temperature change of $1^{\circ} \mathrm{C}$; on the contrary, the thermal conductivity did not appear to be substantially influenced by the temperature of the solution.

The present research represents a first attempt to measure total solids and fat content of egg mixtures by means of electrical and thermal properties. Further investigations could be carried out in order to improve the predictive power of the models, by studying the effect of different oscillating frequencies and voltages that affect the dissociation of the conductive solutions.

\section{References}

Ahmed J., Rahman M.S., Thermal Conductivity Measurement of Foods in Food Properties Handbook, Second Edition. 2008, Taylor \& Francis Group, LLC.

Ahn D.U., Kim S.M., Shu H., Effect of egg size and strain and age of hen on the solids content of chicken eggs. Poultry Science, 1997, 76, 914-919.

Amiali M., Ngadi M.O., Raghavan V.G.S., Nguyen D.H., Electrical conductivities of liquid egg products and fruit juices exposed to high pulsed electric fields. International Journal of Food Properties, 2006, 9 533-540.

AOAC, Association of Official Analytical Chemists. Official method No. 925.30. Gaithersburg, 1990, MD 20877-2417, USA.

Barron J.J., Ashton C., The effect of temperature on conductivity measurements. Technical papers 2007, (http://www.reagecon.com/techpapers.shtml).

Coimbra J.S.R., Gabas A.L., Minim L.A., Garcia Rojas E.E., Telis V.R.N., Telis-Romero J., Density, heat capacity and thermal conductivity of liquid egg products. Jour- nal of Food Engineering, 2006, 74, 186-190.

Figura L.O., Teixeira A.A., Electrical properties. In Food Physics, 2007, Springer-Verlag Berlin Heidelberg.

Fletcher D.L., Britton W.M., Pesti G.M., Rahn A.P., Savage S.I., The relationship of layer flock age and egg weight on egg component yields and solids content. Poultry Science, 1983, 62 1800-1805.

Folch J., Lees M., Stanley G.H.S., A simple method for the isolation and purification of total lipids from animal tissues. Journal of Biological Chemistry, 1957, 226, $497-$ 509.

Fontana A.J., Varith J., Ikediala J., Reyes J., Wacker B., Thermal properties of selected foods using a dual needle heat-pulse sensor. ASAE Meeting Presentation, 1999. Toronto, Ontario Canada.

Fryer P.J., de Alwis A.A.P., Koury E., Stapley A.G.F., Zhang L., Ohmic processing of solid-liquid mixtures: heat generation and convention effects. Journal of Food Engineering, 1993, 18, 101-125.

Funk E.M., The relation of the yolk index determined in natural position to the yolk index, as determined after separating the yolk from the albumen. Poultry Science, 1948, 27, 367.

Gut J.A.W., Pinto J.M., Gabas A.L., Telis-Romero J., Continuous pasteurization of egg yolk: thermophysical properties and process simulation. Journal of Food Process Engineering, 2005, 28, 181-203.

Henningsson M., Östergren K., Dejmek P., The electrical conductivity of milk-the effect of dilution and temperature. International Journal of Food Properties, 2005, 8, $15-22$.

ISO 7888:1985 "Water Quality - Determination of Electrical Conductivity".

Paquet J., Lacroix C., Audet P., Thibault J., Electrical conductivity as a tool for analysing fermentation processes for production of cheese starters. International Dairy Journal, 2000, 10, 391-399.

Radiometer Analytical SAS. Conductivity Theory and Practice, 2004, D61M002 France.

Sampedro F., Rivas A., Rodrigo A., Martínez A., Rodrigo M., Pulsed electric fields inactivation of Lactobacillus plantarum in an orange juice-milk based beverage: effect of process parameters. Journal of Food Engineering 2007, 80, 931:938.

Washburn K.W., Genetic variation in the chemical composition of the egg. Poultry Science, 1979, 58, 529-535.

Żywica R., Pierzynowska-Korniak G., Wójcik J., Application of food products electrical model parameters for evaluation of apple purée dilution. Journal of Food Engineering, 2005, 67, 413-418.

\section{SUMMARY}

The total solids and fat contents of nine whole liquid egg products were assessed by means of electrical and thermal conductivity measurements. Linear correlations between conductivity values and total solids and fat contents were obtained with $\mathrm{R}^{2}$ values up to 0.995 and 0.990 and maximum errors of predic- 
tion up to $0.41 \%$ and $0.42 \%$, respectively.

The electrical conductivity of the albumen, yolk and egg mixtures linearly increased with temperature; at $20^{\circ} \mathrm{C}$, temperature coefficients of $2.1 \% /{ }^{\circ} \mathrm{C}, 2.1 \% /{ }^{\circ} \mathrm{C}$ and $1.9 \% /{ }^{\circ} \mathrm{C}$ were respectively calculated. On the contrary, the thermal conductivity of the analysed products did not appear to be substantially influenced by the temperature of the liquid.

Keywords: whole liquid egg products, total solids content, fat content, electrical conductivity, thermal conductivity. 
